\title{
PCNA and GSK3 $\beta$ interact with each other to regulate H1299 lung adenocarcinoma cells apoptosis
}

\author{
X. H. LIU' ${ }^{1, *}$, D. E. TANG ${ }^{2, *}$, Y. DAI ${ }^{2}$, X. J. GAO ${ }^{1, *}$, L. X. LIU $^{1, *}$ \\ ${ }^{1}$ Key Laboratory of Functional Protein Research of Guangdong Higher Education Institute, Institute of Life and Health Engineering, College of \\ Life Science and Technology, Jinan University, Guangzhou, Guangdong, China; ${ }^{2}$ Clinical Medical Research Center, Shenzhen People's Hospital \\ (The Second Clinical Medical College of Jinan University), Shenzhen, Guangdong, China
}

${ }^{*}$ Correspondence: langxialiu@gmail.com; tgaoxj@jnu.edu.cn

\#Contributed equally to this work.

Received January 16, 2019 / Accepted May 22, 2019

\begin{abstract}
Glycogen synthase kinase beta (GSK3 $\beta$ ) is considered as a promising target for lung cancer treatment and its inhibitor lithium chloride $(\mathrm{LiCl})$ is widely regarded as having potent anti-proliferative and apoptosis-modulating activities. Proliferating cell nuclear antigen (PCNA), as an auxiliary protein for DNA polymerase delta, which regulates DNA replication and repair, has been reported to play an important role in regulating apoptosis. Here, we showed that GSK3 $\beta$ interacted with PCNA in H1299 lung adenocarcinoma cells using GST pull-down and co-immunoprecipitation experiments. We discovered that their interaction can be enhanced within the first $3 \mathrm{~h}$ after UVC irradiation and decreased gradually with time. Overexpression of PCNA protein decreased GSK3 $\beta$ Ser9 phosphorylation, whereas knockdown of PCNA using small interfering RNA (siRNA) increased Ser9 phosphorylated GSK3 $\beta$, which was attenuated by phosphatidylinositol 3-kinase (PI3K) inhibitor LY294002 after UVC irradiation, indicating the involvement of the PI3K-AKT pathway. Functional analyses suggested that downregulation of PCNA sensitized H1299 cells to LiCl-induced apoptosis. Thus, our results unraveled a novel regulatory of GSK3 $\beta$ by PCNA and provided a promising direction for treatment of lung cancer.
\end{abstract}

Key words: apoptosis, GSK3 $\beta$, interaction, NSCLC, PCNA

Lung cancer is considered to be a malignant tumor with the highest morbidity and mortality [1]. The prognosis of lung cancer mainly depends on the timely detection. For example, the 5-year survival rate of patients with early and non-metastatic tumors is about $53 \%$, the 5 -year survival rate of patients with local metastasis is $24 \%$, and the 5 -year survival rate of patients with advanced metastasis of lung cancer is $4 \%$ in the United States. A small number of lung cancers can be diagnosed at the early stage, however the majority is already at a distant stage when discovered [2]. Although significant progress has been made in reducing mortality from other cancers, treatment options for lung cancer are limited. The treatment of lung cancer is particularly complex due to the high tumor heterogeneity of non-small cell lung cancer (accounting for 80\% of reported lung cancer cases), and more work needs to be done to expand the target and signaling pathways of the targeted therapy.

The serine/threonine protein kinase glycogen synthase kinase-3 beta (GSK3 $\beta$ ) is implicated in the hormonal control of several physiological functions, including embryonic development, glycogen metabolism, insulin reaction, migration, cell proliferation and apoptosis [3]. GSK3 $\beta$ is able to phosphorylate a number of downstream carcinogens, such as $\beta$-catenin, c-Myc, c-Jun, cyclin D1 and thus inhibiting their functions. However, GSK3 $\beta$ loses its kinase activity when phosphorylated at the serine 9 [4-7]. The role of GSK3 $\beta$ in cancer is bifunctional or conflicting. Under many conditions, such as DNA damage [8], hypoxia [9], endoplasmic reticulum stress [10], heat shock [11], GSK3 $\beta$ plays a role in inducing apoptosis. Furthermore, inhibition of GSK-3 $\beta$ has been reported to attenuate apoptosis in some cultured neurons cells, such as mouse hippocampal HT-22 [12], and human SH-SY5Y neuroblastoma cells [11]. On the other hand, in numerous tumor cells, such as glioma cells [13], breast cancer cells [14], osteosarcoma cells [15], microglial cells [16], inhibition of GSK3 $\beta$ activity or knockdown of GSK3 $\beta$ protein expression has been reported to activate apoptotic signaling pathways. Even so, small molecule inhibitors of GSK3 $\beta$ are gaining more attention for the development of antitumor drugs. Jing Zeng et al. reported 
that abnormal expression of GSK3 $\beta$ was indicative of poor prognosis for non-small cell lung cancer (NSCLC) and the downregulation of GSK3 $\beta$ attenuated tumor recurrence by increasing apoptosis, inhibiting cell proliferation and migration [7]. In summary, all of these imply that GSK3 $\beta$ may be an important biological target for lung cancer treatment [17].

Proliferating cell nuclear antigen (PCNA) is characterized as an auxiliary protein for DNA polymerase delta to regulate DNA replication in eukaryotic cells, and is also considered as a molecular marker for cell proliferation [18]. Three identical PCNA molecules form a trimeric structure around the DNA double helix, which provides an important platform for the dynamic recruitment and coordinated regulation of a large number of proteins. Subsequently, people further understood the indispensable regulatory role of PCNA in DNA repair, chromatin metabolism, cell cycle control, cell apoptosis and other important cell functions [18, 19]. The expression of PCNA in various tumors is closely related to the degree of malignancy, distant metastasis, disease stage and prognosis [20-23]. Volm et al. found that the survival time of lung cancer patients with a high proportion of PCNA-positive cells was shorter than that of patients with a low proportion of PCNA-positive cells [24]. However, the precise mechanism involved remains largely unknown. Our previous tandem mass spectrometry (LC-MS/MS) analysis have identified the interaction between GSK3 $\beta$ and PCNA in liver hepatocellular carcinoma HepG2 cells [25]. This finding prompted us to speculate whether the interaction between GSK $3 \beta$ and PCNA might also exist in some lung cancer cells, and whether it might regulate the survival or apoptosis of lung cancer cells. The current study tests this hypothesis.

\section{Materials and methods}

Cell lines and reagents. The H1299 cell line (Center of Cell Resource, Shanghai institute of life science, Chinese academy of sciences) was cultured in Dulbecco's modified Eagle medium (DMEM; Gibco) supplemented with 10\% fetal bovine serum (FBS; Gibco) at $37^{\circ} \mathrm{C}$ in a cell incubator. Transfection was performed with Lipofectamine 2000 reagent (Invitrogen) when cells confluence rate reached 80-90\%. SDS lysis buffer and LY294002 were purchased from Beyotime Institute of Biotechnology (Jiangsu, China). The pCMV-flagPCNA, pCMV-flag-GSK-3 $\beta$, pEGFP-N ${ }_{1}$-PCNA plasmids and GST-GSK3 $\beta$ plasmids were constructed in our laboratory. $\mathrm{LiCl}$ was purchased from Sigma-Aldrich.

Induction expressions and purification of GST fusion proteins. GST, GST-GSK3 $\beta$, fusion proteins were produced and purified as described previously $[25,26]$. All protein concentrations were determined using a bicinchoninic acid protein assay (Thermo Fisher Scientific).

GST pull-down assays. Equivalent amount (about $1 \mathrm{mg}$ ) of cell lysis solution and $30 \mu \mathrm{g}$ GST protein or GST-GSK3 $\beta$ fusion protein was co-incubated overnight at $4{ }^{\circ} \mathrm{C}$ on a rocker. The protein components bound to GST or GST-GSK3 $\beta$ fusion proteins were isolated by SDS-PAGE electrophoresis and analyzed by standard immunoblotting using PCNA antibody (cat. No. 60097-1-AP; ProteinTech Group). The amounts of GST-tagged fusion proteins were determined by Coomassie brilliant blue (CBB) staining of SDS-PAGE gels.

Co-immunoprecipitation assays. H1299 cells were lysed in a RIPA lysis buffer and then carried out co-immunoprecipitation assays according to the one we described before. Briefly, whole-cell lysate was precleared with protein A/G sepharose (cat. No. SC-2003; Santa Cruz Biotechnology, USA) and non-immunized IgG (Beyotime) successively. The recleared lysate was then incubated with PCNA or GSK3 $\beta$ (cat. No. 9315; Cell Signaling Technology, USA) antibodies at $4^{\circ} \mathrm{C}$ overnight, and then incubated with protein A/G sepharose beads for $4 \mathrm{~h}$ at $4{ }^{\circ} \mathrm{C}$. The beads were then collected and washed three times to remove the nonspecific binding, and the immune complexes were analyzed by western blotting [25].

siRNA transfection. For an effective PCNA-knockdown, two siRNAs mixtures with a final concentration of 100 $\mathrm{nM}$ was used, including the following sequences: PCNA siRNA-1: 5'-GGAGAAAGUUUCAGACUAUdTdT-3', PCNA siRNA-2: 5'-GGAGGAAGCUGUUACCAUAdTdT-3', GSK3 $\beta$ siRNA: 5'-AAGUAAUCCACCUCUGGCUACTT-3', negative control siRNA (NC): 5'-UUCUCCGAACGUGUCACGUTT-3'. The treatment was performed at $24 \mathrm{~h}$ after transfection and the siRNAs was synthesized by Shanghai GenePharma Co., Ltd. (China). The experiment proceeded as described before [26].

Western blotting assay. H1299 cells after transfection with some plasmids or siRNAs were harvested and lysed with a RIPA lysis buffer. Protein concentrations were measured using the BCA kit (Thermo Fisher Scientific). The experiment was carried out in accordance with the standard method. Primary antibodies against the following proteins were used: GSK-3 $\beta$ (cat. No. 9315; Cell Signaling Technology, Massachusetts, USA), PCNA (cat. No. 60097-1-AP; ProteinTech Group, Inc.), phospho-GSK-3 $\beta$ (Ser9) antibody (cat. No. 9323; Cell Signaling Technology), Phospho-Akt (Ser473) (cat. No. 4060; Cell Signaling Technology), Akt (cat. No. 10176-2-AP; ProteinTech Group, Inc.), Histone H3 (cat. No. 17168-1-AP; ProteinTech Group, Inc.), Flag (cat. No. A2220; Sigma), GFP (cat. No. 50430-2-AP; ProteinTech Group, Inc.), Caspase 3 (cat. No. 9662; Cell Signaling Technology), $\beta$-tubulin (cat. No. 10094-1-AP; ProteinTech Group, Inc.), GAPDH (cat. No. ZS-25778, OriGene Technologies, Inc., Beijing, China). GAPDH or $\beta$-tubulin quantification was used to correct for variations in total protein loading. Western blotting bands were quantified using ImageJ software (version number, 1.42; National Institutes of Health, Bethesda).

Confocal immunofluorescence. H1299 cells treated with or without UVC irradiation were subjected to confocal immunofluorescence in accordance with standard protocols [26]. The images were collected by using laser scanning confocal microscopes (LSM700; Zeiss GmbH, Germany). The magnification was $\times 400$. 
TCGA data downloading. The publicly available RNA-Seq data of mRNA level of Lung Adenocarcinoma (LUAD) samples were obtained directly from TCGA data portal (https://portal.gdc.cancer.gov/projects/TCGA-LUAD) via bulk download mode [LUAD (Disease Type), RNA-Seq (Experimental Strategies)] on June 13, 2018. The data was sequenced based on RNA sequencing platform. These downloaded data included a total of 515 LUAD cases, from which 57 paired primary lung adenocarcinoma and adjacent normal samples were picked for analyzing in this study. Gene expression data from RNA-Seq results were quantified by FPKM with the "FPKM.txt.gz" file type. Extracted data were only rounding off values to integers. The data of PCNA and GSK-3 $\beta$ were extracted and analyzed. The differentially expressed genes (DEGs) between the primary tumor and the solid normal tissue samples were identified with Student's T-test. The relationship between the gene expressions was confirmed by Spearman correlation test.

Nuclear and cytoplasmic separation assay. H1299 cells were transformed with or without some siRNAs, and pretreated with UVC irradiation and then subjected to nuclear and cytoplasmic proteins separation in accordance to standard protocols. Then the proteins were proceeded with BCA assay and western blotting assay.

Flow cytometry. H1299 cells were treated as described below, then the cells were collected and stained with Alexa Fluor 488 Annexin-V/PI (HH-V13241, Invitrogen) according to the manufacturer's protocol. Cytometric data analysis was performed by FACS Calibur (BD Biosciences) and Flowjo software. Only live cells analyzed by forward scattering (FSC) and side scattering (SSC) were counted. Statistical analysis was performed on at least 10,000 cells within the gated region.

Statistical analyses. The significant differences between the two groups were analyzed by the two-tailed unpaired Student's t-tests. Significant differences among multiple groups were analyzed by two-way analysis of variance (ANOVA). As for data obtained from the TCGA database, the GSK3 $\beta$ and PCNA expression values were presented in a way as means \pm standard deviation, $n \geq 3$, unless otherwise stated, $\mathrm{p}<0.05$ indicates a statistical difference.

\section{Results}

GSK3 $\beta$ interacted with PCNA in H1299 cells and in vitro. Our previous tandem mass spectrometry (LC-MS/ MS) analysis has detected 114 GSK3 $\beta$-specific binding proteins in HepG2 cells, and PCNA protein was one of those binding proteins [25]. Both of GSK3 $\beta$ and PCNA were related with cell survival/apoptosis, which prompt us to assess the presence of two protein interactions in lung adenocarcinoma cancer H1299 cells and to test their association with apoptosis. Here, we first used GST pulldown assays to detect the specific binding of the two proteins in H1299 cells. The results are shown that purified fusion protein GST-GSK3 $\beta$ can specifically pull down some PCNA proteins in $\mathrm{H} 1299$ cells, even if some of the fusion protein were degraded (represented by ${ }^{\star}$ in Figure 1A). We then performed co-immunoprecipitation experiments to determine the interaction between GSK3 $\beta$ and PCNA in H1299 cells. As shown in Figure 1B and Figure 1C, GSK3 $\beta$
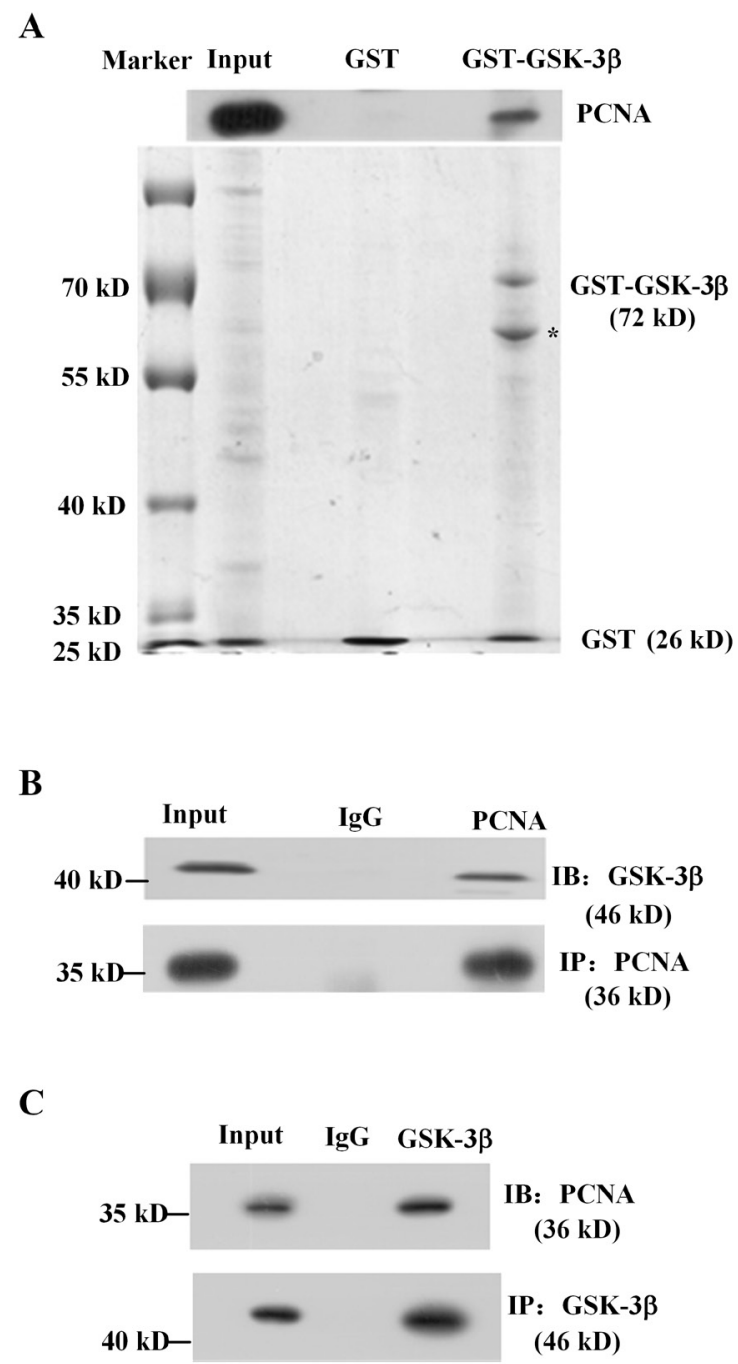

Figure 1. GSK3 $\beta$ interacted with PCNA in cells and in vitro. A) The binding of GSK $3 \beta$ and PCNA was detected by GST pull-down assays. The cell lysates of $\mathrm{H} 1299$ co-incubated with glutathione sepharose beads coated with GST or GST- GSK3 $\beta$ for $4 \mathrm{~h}$. The pulled proteins were analyzed by IB with PCNA antibody (the upper panels), whereas the experimental amounts of GST or GST- GSK $3 \beta$ recombinant proteins are assessed by CBB staining. ${ }^{*}$, degraded GST- GSK3 $\beta$ fusion proteins. B) Co-immunoprecipitations of PCNA and GSK3 $\beta$ using PCNA antibody carried out H1299 cells, followed by western blotting with appropriate antibodies. Non-immune mouse IgG was used as negative control for synchronous experiment. Western blotting reveals the increased amount of GSK3 $\beta$ coimmunoprecipitated with PCNA antigen-antibody complex compared with the control group. Input represents the total amounts of PCNA and GSK3 $\beta$ in the whole cell lysate as internal control. C) Immunoprecipitation experiments using GSK3 $\beta$ antibody were performed with lysates of H1299 cells, and then western blotting was carried out. Non-immune IgG (IgG) was used as the negative control for GSK3 $\beta$ antibody. 
co-immunoprecipitated with PCNA by anti- PCNA antibody in the cell lysate of H1299 cells. PCNA co-immunoprecipitated with GSK3 $\beta$ by anti-GSK3 $\beta$ antibody. Taken together, these results suggested that the interaction between these two proteins existed in H1299 cells.

The interaction between GSK3 $\beta$ and PCNA was transiently enhanced in response to UVC irradiation in H1299. To observe the co-localization of these two proteins in H1299 cells, the confocal immunofluorescence was performed. As shown in Figure 2A, PCNA was mainly distributed in the nucleus with a punctate pattern, as previously described by other researchers, and in these cells, only a tiny amount of GSK and PCNA existed co-localization in the nucleus, since yellow color staining which would have resulted from the co-localization of the two proteins was basically difficult to be observed (the merge panel in Figure $2 \mathrm{~A}$ ). We speculated that the interaction between these two proteins could be possibly mediated by structural changes or modifications in one or both proteins, or perhaps some scaffold proteins or mediator complex. It is possible that under certain physiological conditions, this interaction may be strengthened.

We hypothesized that UVC irradiation, the most common inducer of apoptosis, might affect the interaction between GSK3 $\beta$ and PCNA. We next tested this hypothesis. At different time points $(0,3,6 \mathrm{~h})$ after UVC irradiation at $25 \mathrm{~J} / \mathrm{cm}^{2}$ for 1 $\mathrm{min}$, the co-localization of two proteins was analyzed by laser confocal assay. Three hours after the treatment with UVC irradiation, we observed that GSK $3 \beta$ co-localized with PCNA was increased in the nucleus compared to the untreated cells (Figure 2B, the middle panel). Since then, the co-localization of the two proteins decreased gradually over the time (Figure $2 \mathrm{~B}$, the bottom panel). Then, co-immunoprecipitation experiments further verified that the interaction between PCNA and GSK3 $\beta$ could be enhanced by UVC irradiation within $3 \mathrm{~h}$ (Figure 2C). Interesting, we found that UVC irradiation within $3 \mathrm{~h}$ increased Ser9 phosphorylation of GSK3 $\beta$ (Figure 2D), suggesting that the interaction of the two proteins could be mediated by the Ser9 phosphorylation of GSK3 $\beta$.

The expression of PCNA and GSK $3 \beta$ in LAUD analyzed with TCGA data. Next, we tried to find a functional link between these two proteins. Firstly, we searched and downloaded the cancer genome atlas (TCGA) data for further analysis. Data of paired lung adenocarcinoma and adjacent normal samples were downloaded from TCGA. The results showed that the RNA expression level of PCNA in LUAD was highly overexpressed compared to matched normal tissues $(\mathrm{p}<0.0001)$ (Figure $3 \mathrm{~A})$, whereas GSK3 $\beta$ showed no significant difference between primary tumor and adjacent normal tissues (Figure 3B). Furthermore, no correlation between the mRNA level of PCNA and GSK3 $\beta$ could be established in lung adenocarcinoma (Figure 3C). In order to further determine whether there is a regulatory relationship between the expression of PCNA and GSK $3 \beta$, western blot assays were performed with protein extracts from the
H1299 cells transformed with pCMV-flag-GSK3 $\beta$ or pCMVflag-PCNA plasmid using specific anti-GSK3 $\beta$ or anti-PCNA antibodies. It was revealed that, PCNA overexpression had no effect on the GSK3 $\beta$ protein expression level, and likewise, GSK3 $\beta$ overexpression had no effect on the PCNA protein expression level (Figure 3D).

To further investigate the role of GSK-3 $\beta$-PCNA interaction, H1299 cells were either overexpressed Flag-GSK-3 $\beta$ or EGFP-PCNA exogenous protein, and then treated or untreated with UVC irradiation at $25 \mathrm{~J} / \mathrm{cm}^{2}$ for $1 \mathrm{~min}$. Western blot assay and Annexin V/PI double staining with a FACS Calibur flow cytometer were performed. As shown in Figure $4 \mathrm{~A}$ and $4 \mathrm{~B}$, the level of cleaved Caspase 3, indicators of the degree of apoptosis, were decreased when cells were transfected by Flag-GSK-3 $\beta$ or EGFP-PCNA plasmids and then treated with UVC. Also, similar effects on cell apoptotic rates in FACS assays were observed in cells overexpressing Flag-GSK-3 $\beta$ or EGFP-PCNA and then treated with UVC (Figures $4 \mathrm{C}$ and $4 \mathrm{D}$ ). Combination of the above experimental results, we hypothesized that the interaction between GSK- $3 \beta$ and PCNA might be involved with UVC-induced apoptosis. Next, we will test this hypothesis.

PCNA downregulated the Ser9 phosphorylation of GSK3 $\beta$ in H1299 cells possibly via PI3K-AKT pathway after UVC irradiation. Our previous study has shown that ectopic expression of Flag-PCNA mitigated degree of DNA damage induced by UVC irradiation, which protected cells from apoptosis in 293 cells [27]. UV irradiation is an ideal tool to study the apoptotic behavior [28], within which UVC light has the strongest carcinogenic and cytotoxic effect [29], and it targets both membrane receptors and nuclear DNA, promoting apoptosis. The present study subsequently aimed to investigate whether the interaction between GSK3 $\beta$ and PCNA could be associated with the process of UVC-induced apoptosis, either PCNA or GSK-3 $\beta$ was knocked down with a specific siRNA in H1299 cells, then the cells were irradiated with UVC [30]. After $3 \mathrm{~h}$, nuclear and cytoplasmic protein extraction experiment and western blot assays were performed to analyze the cellular localization and expression level of GSK3 $\beta$ and PCNA. As shown in Figure 5A, PCNA protein accumulated in the nucleus after UVC irradiation, whereas GSK3 $\beta$ showed no significant change in expression and localization after UVC irradiation. Although PCNAknockdown had no effect on the expression and cellular localization of total GSK3 $\beta$, its decreased expression significantly increased the Ser9 phosphorylation of GSK $3 \beta$ both in the nucleus and cytoplasm (Figures 5B and 5D). These results suggested that PCNA may downregulate the Ser9 phosphorylation of GSK3 $\beta$ in H1299 cells after UVC irradiation. To further confirm this result, H1299 cells were transformed with pCMV-flag-PCNA or pCMV-flag empty vector for $24 \mathrm{~h}$ and then exposed to UVC irradiation. The results indicated that PCNA-overexpression could inhibit GSK3 $\beta$ Ser9 phosphorylated, while the level of total GSK3 $\beta$ remained unaffected (Figures 5C and 5D). 
A

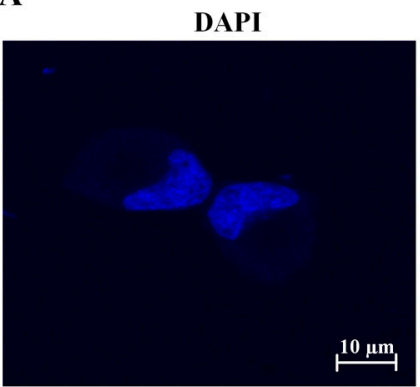

PCNA

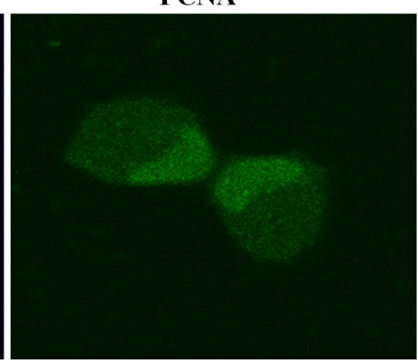

B
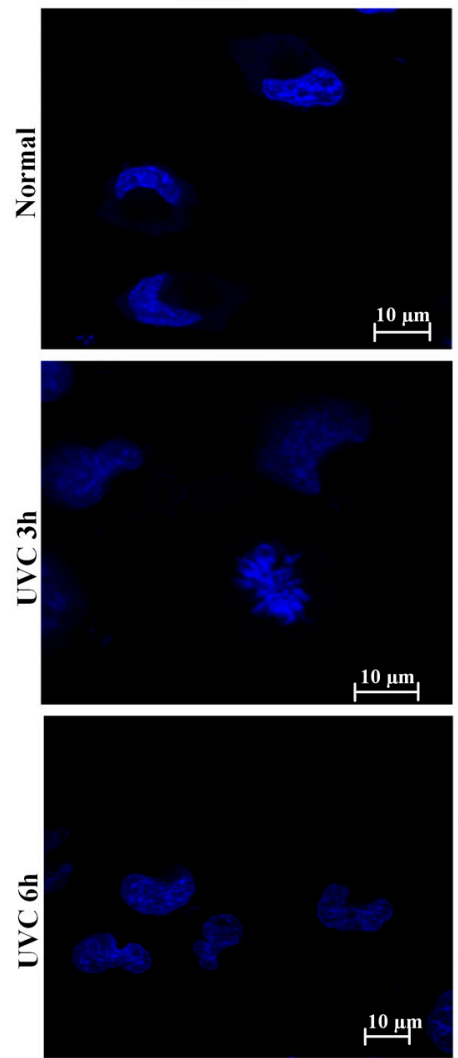

C

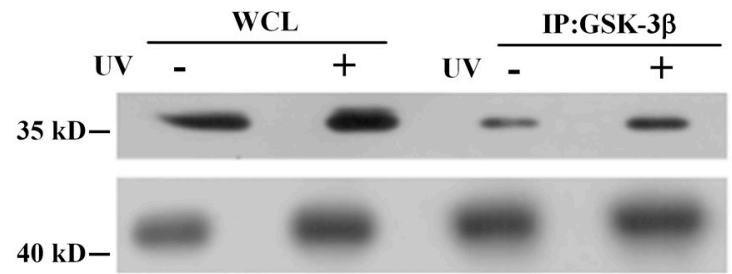

PCNA
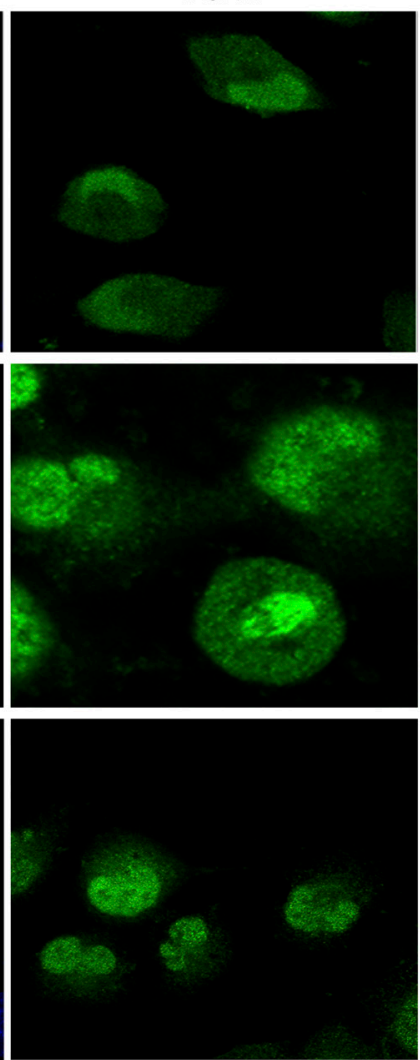

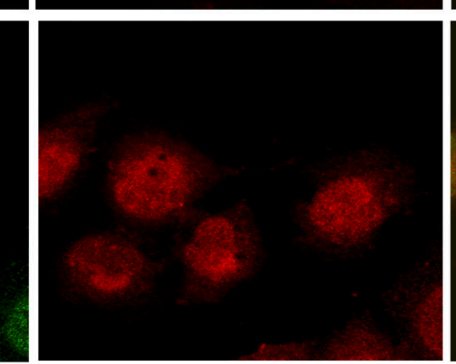

D

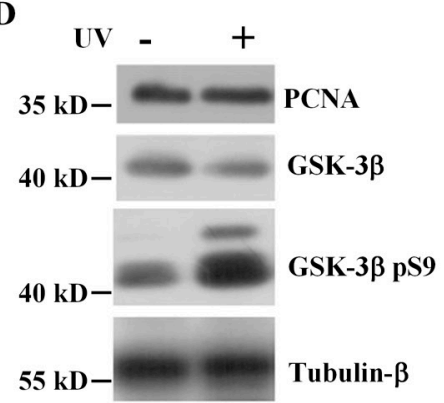

Figure 2. The interaction between GSK3 $\beta$ and PCNA was transiently enhanced in response to UVC irradiation. A) H1299 cells were fixed and immunostained with anti- GSK3 $\beta$ (red), anti- PCNA antibody (green), and DAPI (blue). B) H1299 cells were treated with or without UVC irradiation at 25 $\mathrm{J} / \mathrm{cm}^{2}$ for $1 \mathrm{~min}$ at different time points $(0 \mathrm{~h}, 3 \mathrm{~h}, 6 \mathrm{~h})$ and then immunofluorescence assay was performed. Arrows: the co-localization of the two proteins. Bar: $10 \mu \mathrm{m}$. C) $\mathrm{H} 1299$ cells were treated with or without UVC irradiation at $25 \mathrm{~J} / \mathrm{cm}^{2}$ for $1 \mathrm{~min}$, followed by immunoprecipitation experiments within $3 \mathrm{~h}$ using the indicated antibodies. D) Western blotting was carried out to analyze the interest protein expression within the first $3 \mathrm{~h}$ after $\mathrm{UVC}$ irradiation using the indicated antibodies. 
A

PCNA expression level

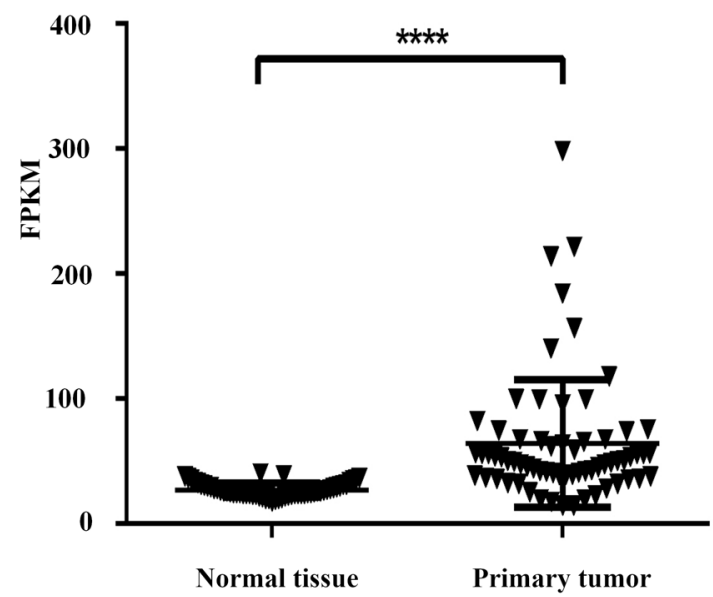

C

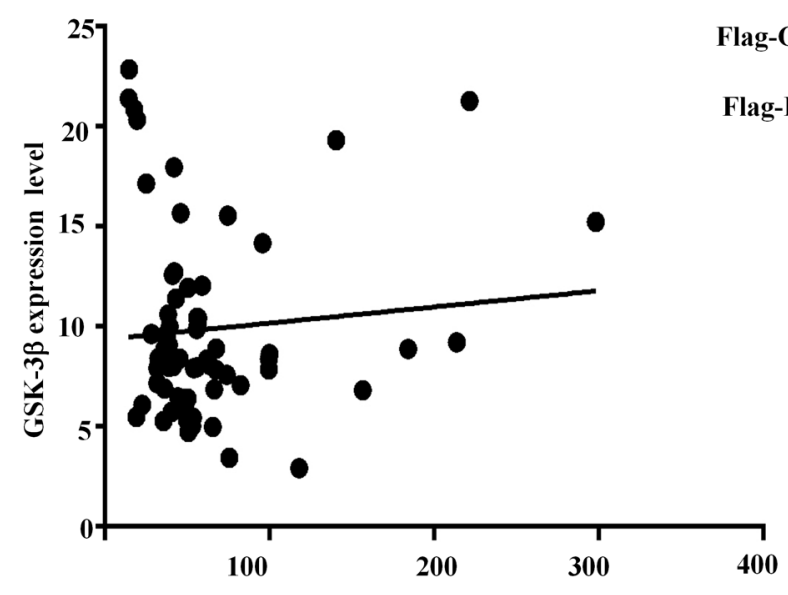

B

GSK-3 $\beta$ expression level

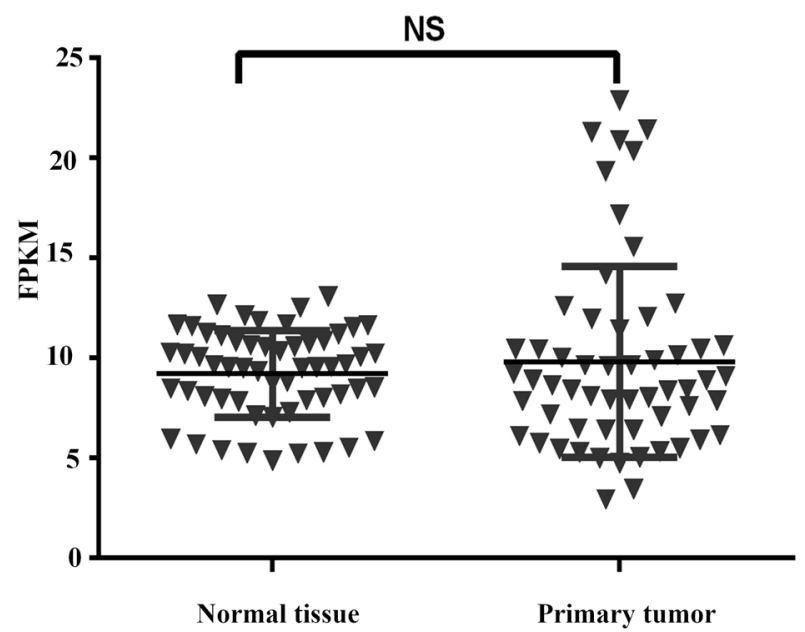

D

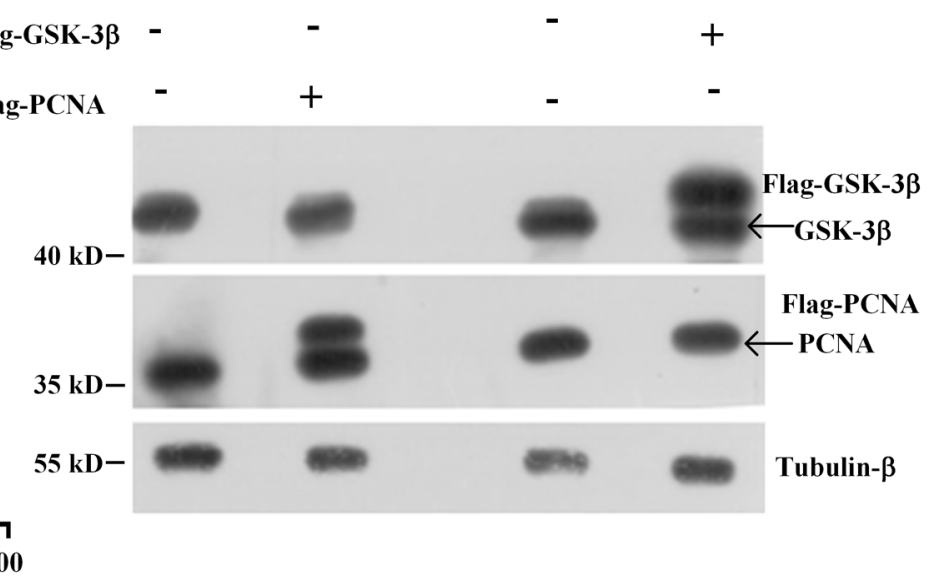

PCNA expression level

Figure 3. The expression of PCNA and GSK3 $\beta$ in LAUD analyzed with TCGA data. A) GSK3 $\beta$ expression level of 57 LAUD tissues from TCGA database showed no significantly difference compared with corresponding non-tumor normal tissues. $p=0.382$. B) PCNA expression level of 57 LAUD tissues from TCGA database was significantly higher compared with corresponding non-tumor normal tissues. ${ }^{* * *} \mathbf{p}<0.0001$. C) The relationship between GSK $3 \beta$ and PCNA was confirmed by Spearman correlation test $(r=0.067 ; p=0.622)$. D) H1299 cells were either transfected with flag-PCNA plasmids or Flag-GSK $3 \beta$ plasmids and their respective negative controls and analyzed by western blotting using the indicated antibodies.

Serine/threonine kinase $\mathrm{PKB} / \mathrm{Akt}$ has been reported to phosphorylate and inactivate GSK3 $\beta$ on its Ser9 residue [31, 32]. Notably, the protein kinase Akt/PKB has been activated after UVC irradiation in NIH3T3 cells, and also has been shown to protect keratinocytes from the toxic effects of UVC irradiation [30]. The activity of Akt kinase is mainly regulated by phosphatidylinositol 3-kinase (PI3K), and its two key phosphorylation sites are Ser473 and Thr308, respectively $[30,31]$. Once Ser473 is phosphorylated, Akt kinase is fully activated independent of Thr308 status [32]. Therefore, we investigated whether PCNA inhibited the Ser9 phosphorylation of GSK3 $\beta$ was via PI3K-Akt pathway in H1299 cells.
H1299 cells were transformed with PCNA siRNA or negative controls, and then irradiated with UVC as described above. The results indicated that PCNA-knockdown significantly increased both the Ser 9 phosphorylation of GSK3 $\beta$ and the Ser473 phosphorylation of Akt (Figure 5E). Subsequently, experiments were performed by combining PCNA-knockdown with LY294002, an inhibitor of PI3K, which acts on the ATP binding site of the catalytic subunit [33, 34]. H1299 cells transformed with PCNA siRNA or negative controls were treated or untreated with LY294002, and then exposed to UVC irradiation and subjected to western blot analyses for the assessment of the expression and phosphorylation 
A

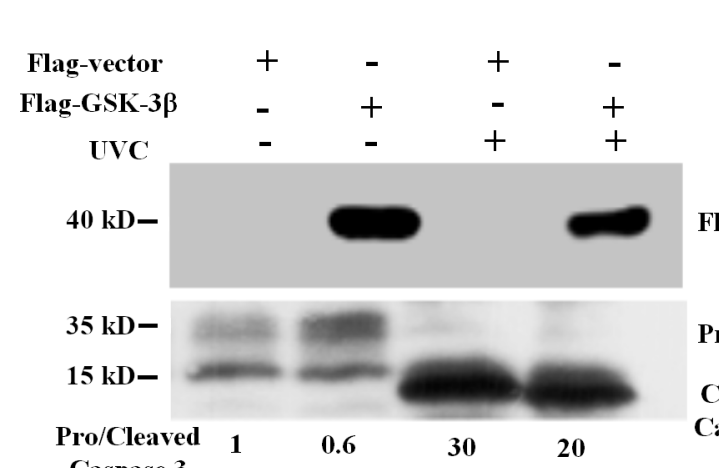

Caspase 3

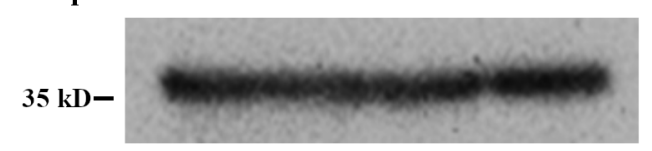

B

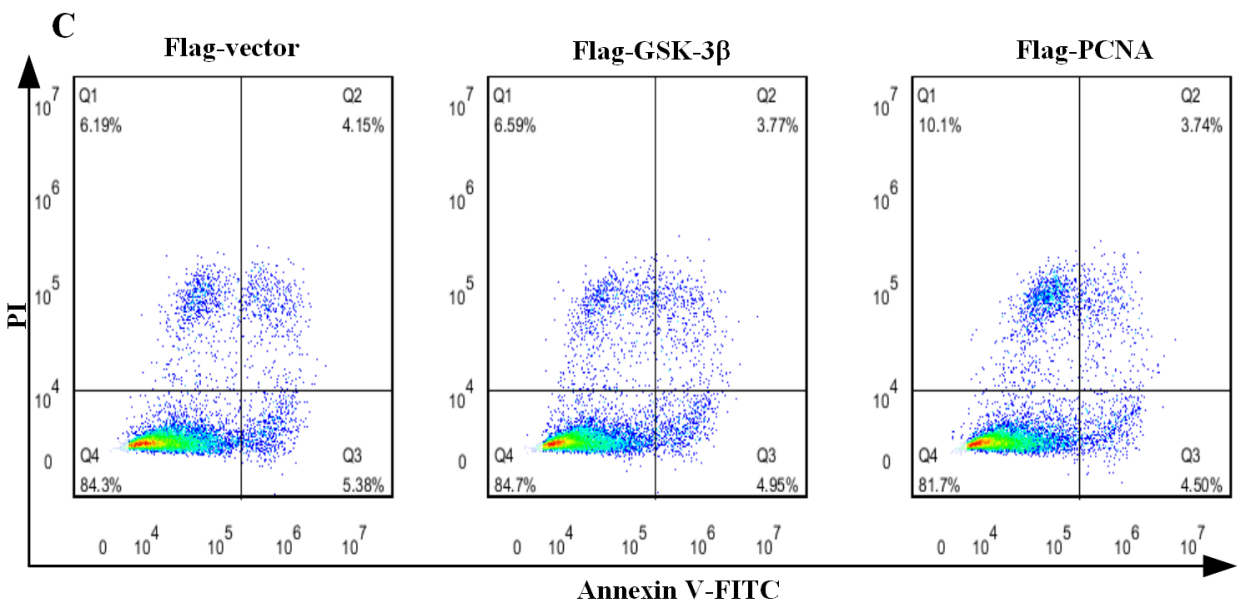

Pro-

Cleaved-

Caspase 3

$\begin{array}{lllll}\text { EGFP-vector } & + & + & - & - \\ \text { EGFP-PCNA } & - & - & + & + \\ \text { UVC } & - & + & - & +\end{array}$

$35 \mathrm{kD}-$

EGFP

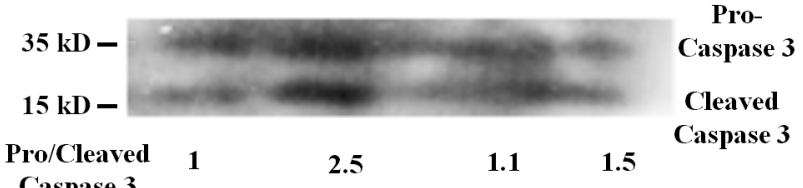

Caspase 3

GAPDH

Tubulin- $\beta$

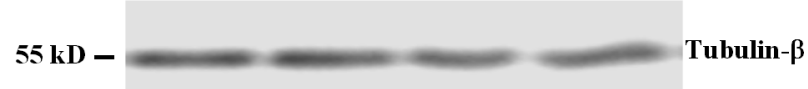

IVC
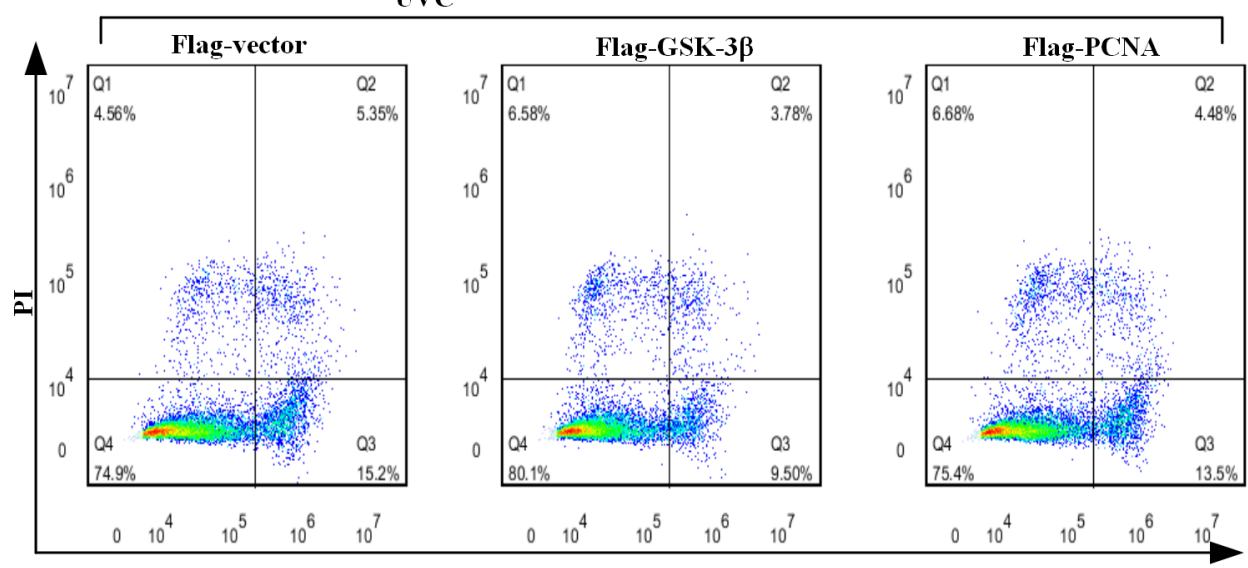

D

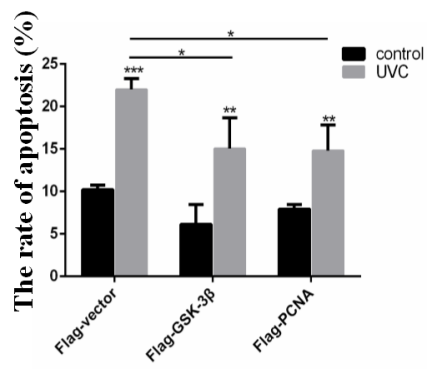

Annexin V-FITC

Figure 4. Both GSK3 $\beta$ and PCNA antagonized UVC-induced cell apoptosis. H1299 cells were either transfected with pCMV-flag-GSK3 $\beta$ (A) or EGFPPCNA plasmid (B) for $24 \mathrm{~h}$, and then treated with UVC irradiation at $25 \mathrm{~J} / \mathrm{cm}^{2}$ for $1 \mathrm{~min}$. Cells were subsequently collected and subjected to western blotting for determination of the levels of cleaved caspase 3. The cleaved caspase 3/Pro-caspase 3 ratio was used to measure the degree of apoptosis. C) H1299 cells were either transfected with pCMV-flag-GSK3 $\beta$ or pCMV-flag-PCNA plasmid for $24 \mathrm{~h}$, and then treated with UVC irradiation at $25 \mathrm{~J} / \mathrm{cm}^{2}$ for $1 \mathrm{~min}$. Cells were then collected $3 \mathrm{~h}$ after UVC irradiation and subjected to Annexin V/PI double staining with a FACS Calibur flow cytometer for determination of cell apoptosis rate. $\mathrm{D})$ The cell apoptosis data including early apoptosis and late apoptosis $(\mathrm{Q} 2+\mathrm{Q} 3)$ were statistically presented. Data are presented as the mean \pm standard deviation, $\mathrm{n} \geq 3,{ }^{*} \mathrm{p}<0.5,{ }^{* *} \mathrm{p}<0.01,{ }^{* * *} \mathrm{p}<0.001$. 
A

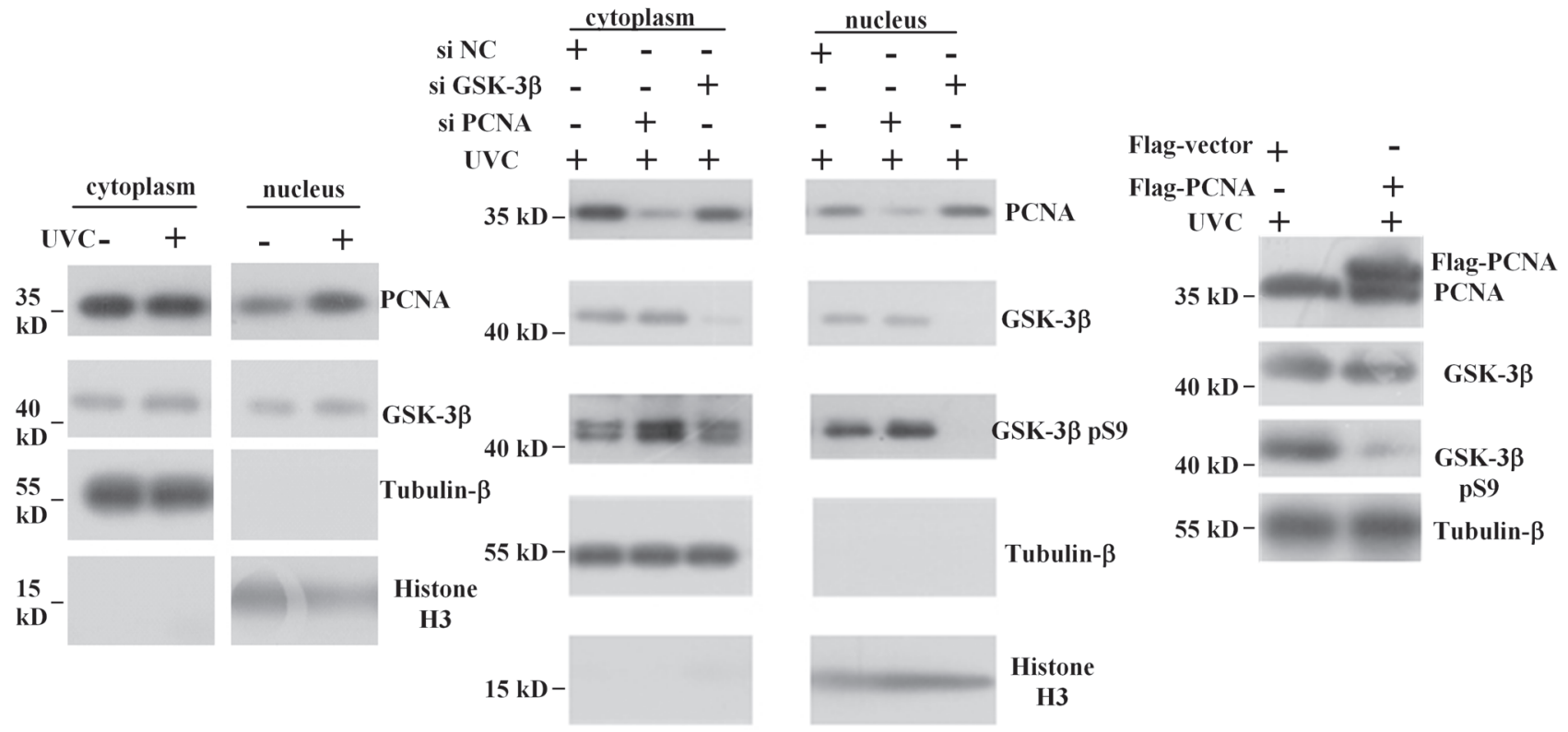

D

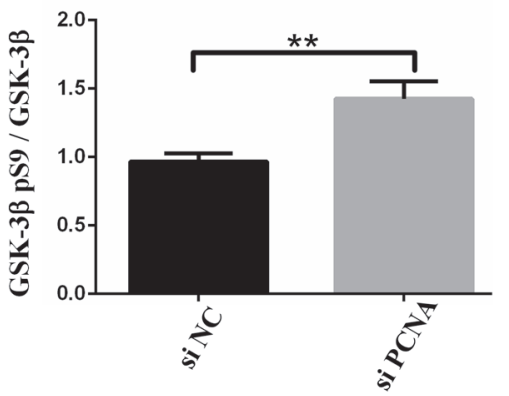

E

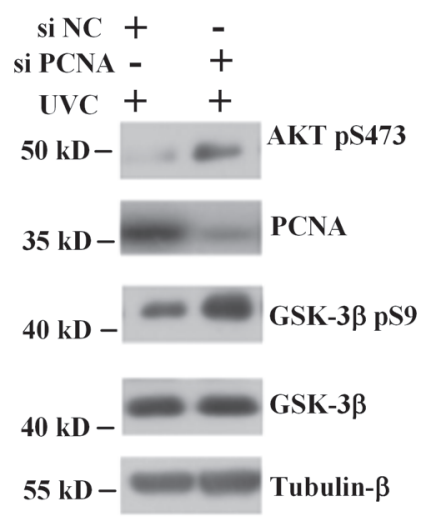

F

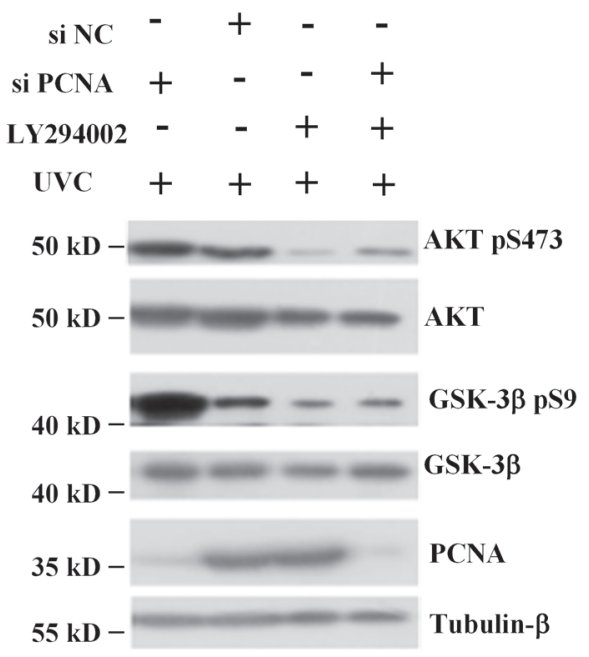

Figure 5. PCNA downregulates GSK3 $\beta$ Ser9 phosphorylation via PI3K-AKT pathway after UVC irradiation. A) H1299 cells were subjected to UVC irradiation at $25 \mathrm{~J} / \mathrm{cm}^{2}$ for $1 \mathrm{~min}$. After $3 \mathrm{~h}$, the extraction of nuclear and cytoplasmic protein was carried out as described in materials and methods. The expression of interest protein was analyzed by western blotting. B) H1299 cells were transfected with either specific PCNA-targeting siRNA or specific GSK3 $\beta$-targeting siRNA or negative control, and then subjected to UVC irradiation at $25 \mathrm{~J} / \mathrm{cm}^{2}$ for $1 \mathrm{~min}$. After $3 \mathrm{~h}$, nuclear and cytoplasmic protein extraction and western blotting assay were performed. C) H1299 cells were transfected with pCMV-flag-PCNA plasmids or pCMV-flag-vectors, then subjected to UVC irradiation at $25 \mathrm{~J} / \mathrm{cm}^{2}$ for $1 \mathrm{~min}$. After $3 \mathrm{~h}$, the proteins were extracted and analyzed by western blotting. D) The signal intensity from the GSK3 $\beta$ pS9 immunoblot was quantified. The results are presented as the fold-changes following normalization using GSK3 $\beta$ and compared with the control group. Data are presented as the mean \pm standard deviation, $n \geq 3,{ }^{* *} p<0.01$. The error bar represents the standard deviation. E) H1299 cells were transfected with either specific PCNA-targeting siRNA or negative control, and then subjected to UVC irradiation at $25 \mathrm{~J} / \mathrm{cm}^{2} \mathrm{for} 1 \mathrm{~min}$. After $3 \mathrm{~h}$, the cells were collected and subjected to western blotting using the indicated antibodies. Tubulin- $\beta$ was used as the sample loading control. F) $\mathrm{H} 1299$ cells transfected with either specific PCNA-targeting siRNA or negative control, prior to being treated with PI3K inhibitor LY294002 (20 $\mu$ M, $12 \mathrm{~h})$ and irradiated with UVC as described above. Then the cells were harvested and analyzed by western blotting. 
levels of GSK3 $\beta$ and Akt. As shown in Figure 5F, Akt was constitutively expressed in all irradiated cells, whereas the promoting effect of siPCNA on GSK3 $\beta$ Ser9 phosphorylation and Ser473 phosphorylation was partially blocked by LY294002. GSK3 $\beta$ knockdown seemed to promote PCNA from cytoplasm into the nucleus (Figure 5B), however, to exclude whether it was just due to the role of PCNA in DNA damage response needs further exploration. Taken together, these results suggested that PCNA was capable of downregulating the Ser9 phosphorylation of GSK3 $\beta$ in H1299 cells after UVC irradiation.

Downregulation of PCNA sensitized H1299 cells to $\mathrm{LiCl}$-induced apoptosis by targeting GSK3 $\beta$. $\mathrm{LiCl}$ is a specific inducer of the inhibitory Ser9 phosphorylation of GSK3 $\beta$ [35]. To further demonstrate the functional role of GSK3 $\beta$-PCNA interaction, H1299 cells transformed with PCNA siRNA or negative controls were treated or untreated with $\mathrm{LiCl}$, and subjected to western blot analyses for the assessment of the levels of apoptosis. As shown in Figure 6A and $6 \mathrm{~B}$, although a less obvious band of cleaved Caspase 3 could be seen on the western blot when H1299 cells were treated with $\mathrm{LiCl}$, significant augmentation of the cleaved Caspase 3 protein level, along with an increase in GSK3 $\beta$ Ser9 phosphorylation, could be detected in the PCNA knockdown cells with the treatment of $\mathrm{LiCl}$. AnnexinV/PI staining further confirmed that si-PCNA enhanced LiCl-induced apoptosis (Figures 6C and 6D). These results provided a potential therapeutic strategy to enhance GSK3 $\beta$-targeted cancer therapy.

\section{Discussion}

PCNA has no intrinsic enzymatic activity and its main function is to construct a scaffold, recruit other proteins and perform different physiological functions $[36,37]$. In the present study, we showed that PCNA interacted with GSK3 $\beta$ in H1299 cells and in vitro (Figure 1), and UV irradiation increased transiently the co-localization of the two proteins (Figure 2). The previous studies have identified a broad and functionally important PCNA-binding motif called PIP box, with sequence $\mathrm{QXX}(\mathrm{M} / \mathrm{L} / \mathrm{I}) \mathrm{XX}(\mathrm{F} / \mathrm{Y})(\mathrm{F} / \mathrm{Y})$, where " $\mathrm{X}$ " is any amino acid $[38,39]$. Gilljam et al. also showed that AlkB homologue 2 PCNA-interacting motif (APIM), a novel motif that interacted with a post-translationally modified PCNA via the sequence $\mathrm{MD}(\mathrm{L} / \mathrm{R}) \mathrm{W}(\mathrm{L} / \mathrm{V} / \mathrm{I}) 2(\mathrm{~K} / \mathrm{R})$, which was found in more than 200 nuclear proteins and related to DNA stability, transcription and cell cycle control [39]. However, sequencing analysis revealed that neither PIP box nor APIM motif was included in the amino acid sequence of GSK $3 \beta$, and we speculated that binding and co-localization between the two proteins were likely to be mediated by a structural change or post-translationally modification of GSK3 $\beta$ (phosphorylation, ubiquitination, SUMOylation, acetylation, methylation, and nitrosylation), or by some unknown non-classical PCNA-binding motif in the amino acid sequence of GSK3 $\beta$. The interaction between GSK3 $\beta$ and PCNA was rapidly increased along with increased serine 9 phosphorylation of GSK3 $\beta$ after UVC irradiation within the first 3 hours (Figure 2), hinting on an enhanced physical interaction associated with Ser9 phosphorylation of GSK3 $\beta$.

GSK3 $\beta$ has been reported as a promising lung cancer therapeutic target. Jing Zeng et al. have reported that GSK3 $\beta$ inhibition reduces proliferation and survival of non-small cell lung cancer cells and its overexpression is closely related to poor prognosis. The present study demonstrated that both PCNA and GSK3 $\beta$ reduced apoptosis-inducing potential of UVC in H1299 cells (Figure 4), and PCNA positively regulated GSK3 $\beta$ activity after UVC irradiation in H1299 NSCLC cells (Figures 5B-D), implying that PCNA might play an anti-apoptotic role by regulating the function of GSK $3 \beta$.

In the present study, the effect of PCNA-knockdown on enhanced serine 9 phosphorylation of GSK3 $\beta$ in H1299 NSCLC cells after UVC irradiation, could be partially diminished by LY294002, an inhibitor of PI3K (Figures 5E and F). This highlights the role of PI3K-AKT-GSK3 $\beta$ signaling pathways involved in UVC-induced apoptosis in H1299 cells. It is well known that growth factors activate the cell survival pathway via the PI3K-Akt pathway and suppress the induction of apoptosis. After phosphorylated at Ser473 by PI3K, AKT directly phosphorylates and inhibits the pro-apoptotic protein $\mathrm{BAD}$ [40]. BAD can form heterodimers with antiapoptotic proteins $\mathrm{Bcl}-\mathrm{X}_{\mathrm{L}}$ and $\mathrm{Bcl}-2$, whereas phosphorylated $\mathrm{BAD}$ cannot bind these proteins, which contributes to cell survival [41-43]. However, further research needs to be done to test whether PCNA upregulates the Ser9 phosphorylation of GSK $3 \beta$ via PI3K-AKT pathway and how the interaction between the two proteins regulate apoptosis after UVC irradiation.

PCNA has been demonstrated to play a critical role in DNA damage detection and repair [13, 19, 44, 45]. The main function of PCNA in the nucleus is to control the replication fork, which is considered as a potential target to inhibit the proliferation of cancer cells. Notably, recent studies suggest that PCNA may also be involved in apoptosis. Lithium, the GSK3 inhibitor, has been reported to modulate cell growth and apoptosis in a variety of cancers and thus considered as an anti-cancer agent [46-48]. Lan et al. reported that lithium enhanced TRAIL-induced apoptosis in A549 NSCLC cells [49]. However, our results showed that $\mathrm{LiCl}$ did not induce obvious apoptosis in H1299 cells, while PCNA knockdown cells with the treatment of $\mathrm{LiCl}$ exhibited a significant increase of apoptosis, which may provide new strategies for combination therapy of NSCLC (Figure 6). In addition, it would make sense to repeat these experiments in other lung adenocarcinoma cells, and this is our next step.

Our observations indicated that PCNA in H1299 cells is likely to play an important regulatory role in UVC-induced apoptosis by the interaction with GSK3 $\beta$, which reveal a novel, additional, regulatory mechanism of GSK3 $\beta$ and suggest a promising candidate therapy for the treatment of human non-small cell lung cancer. 
A

LiCl

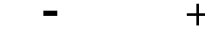

$40 \mathrm{kD}-$

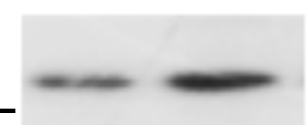

GSK-3 $\beta$ pS9

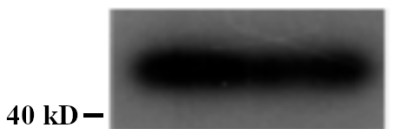

GSK-3 $\beta$

$40 \mathrm{kD}-$

$35 \mathrm{kD}-$

$35 \mathrm{kD}-$

$15 \mathrm{kD}-$
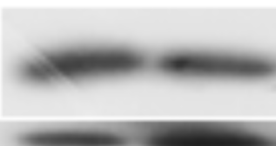

PCNA

Pro-Caspase 3

Cleaved Caspase 3

Tubulin- $\beta$
B

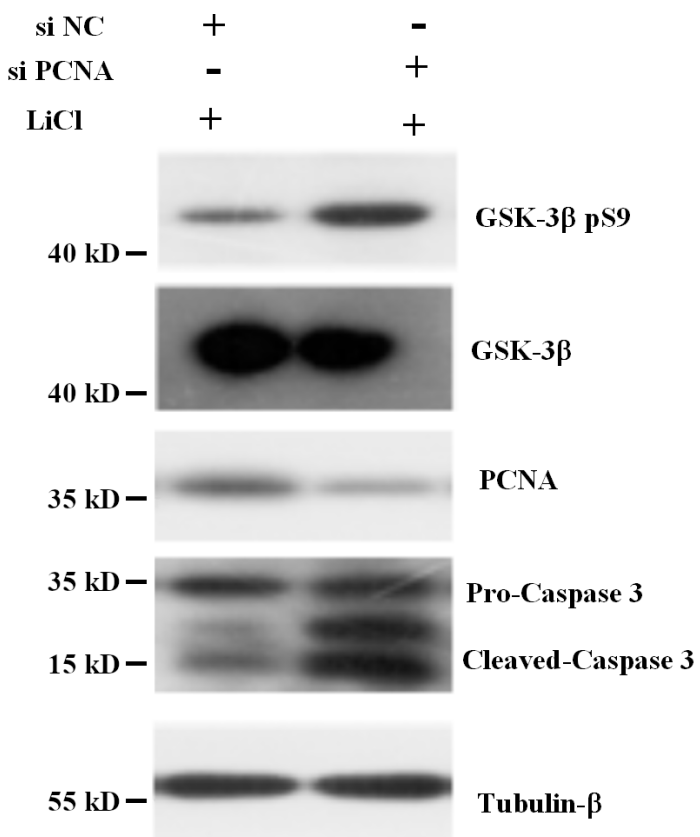

C

LiCl
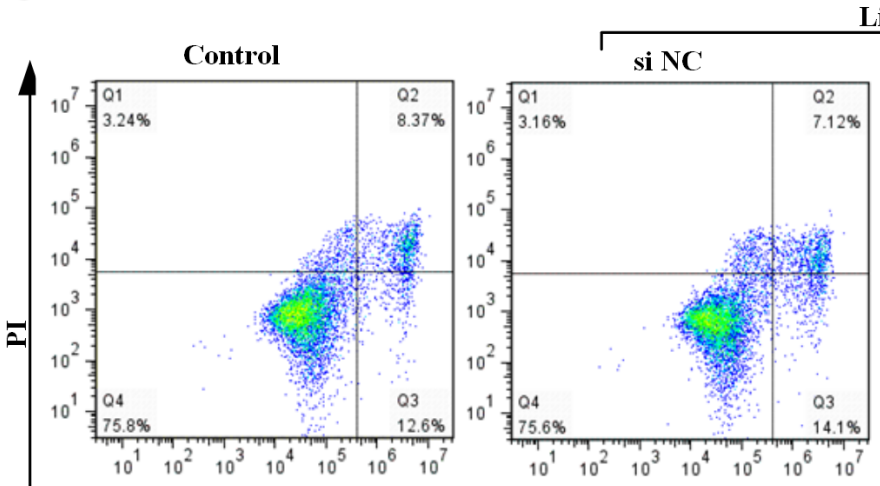

si PCNA

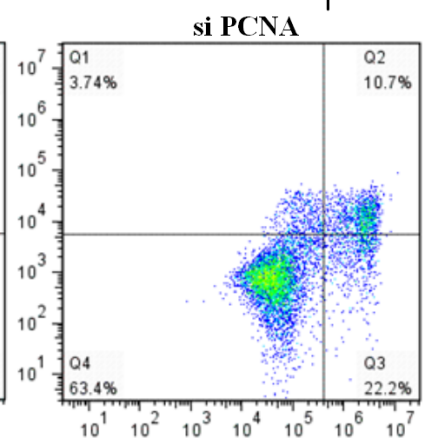

Annexin V-FITC

D

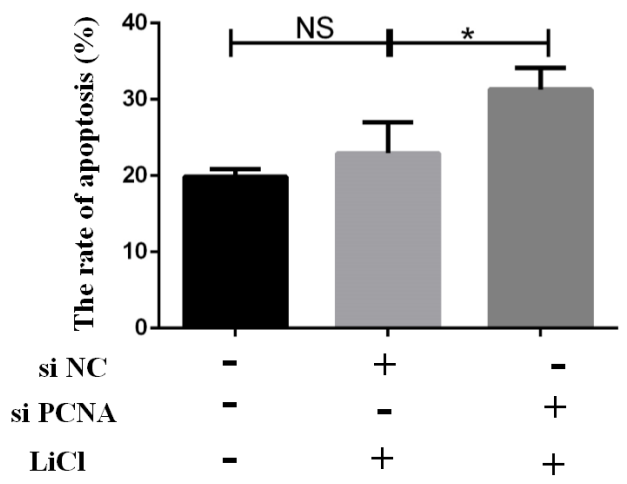

Figure 6. Downregulation of PCNA sensitized H1299 cells to LiCl-induced apoptosis by targeting GSK3ß. A) H1299 cells were treated with GSK3 $\beta$ inhibitor $\mathrm{LiCl}(20 \mathrm{mM}, 8 \mathrm{~h})$, and then analyzed by western blotting. B) $\mathrm{H} 1299$ cells were transfected with either specific PCNA-targeting siRNA or negative control, prior to being treated with $\mathrm{LiCl}(20 \mathrm{mM}, 8 \mathrm{~h})$, and then analyzed by western blotting. C) $\mathrm{H} 1299$ cells were transfected with either specific PCNA-targeting siRNA or negative control, prior to being treated with or without $\mathrm{LiCl}(20 \mathrm{mM}, 12 \mathrm{~h})$, and then analyzed by Annexin V/PI double staining. D) The cell apoptosis data including early apoptosis and late apoptosis $(\mathrm{Q} 2+\mathrm{Q} 3)$ were statistically presented. Data are presented as the mean \pm standard deviation, $\mathrm{n} \geq 3,{ }^{*} \mathrm{p}<0.5$. 
Acknowledgements: The present study was supported by grants from the Guangdong Natural Science Foundation, Guangdong, China (grant No. 2016A030313083, 2017A030310629 and 2018A030313544); the Science and Technology Program of Guangzhou, Guangdong, China (grant No. 201607010175 and 201707010263); the National Natural Science Foundation of China (Grant No. 81671596) and the National Science Foundation for Young Scientists of China (Grant No. 31700795); Science and Technology Planning Project of Guangdong Province, China (Grant No. 2017B020209001); Science and Technology Planning Project of Guangdong Province, China (Grant No. 2016A050503009); the science and technology plan of Shenzhen (Grant No. JCYJ20160422164313440).

\section{References}

[1] GINSBERG MS. Epidemiology of lung cancer. Semin Roentgenol 2005; 40: 83-89. https://doi.org/10.1053/j. ro.2005.01.007

[2] DESANTIS C, LIN CC, MARIOTTO AB, SIEGEL RL, STEIN KD et al. Cancer treatment and survivorship statistics, 2014. CA Cancer J Clin 2014; 64: 252-271. https://doi. org/10.3322/caac. 21235

[3] CROSS DA, ALESSI DR, COHEN P, ANDJELKOVICH M, and HEMMINGS BA. Inhibition of glycogen synthase kinase- 3 by insulin mediated by protein kinase B. Nature 1995; 378: 785-789. https://doi.org/10.1038/378785a0

[4] WOODGETT JR. Molecular cloning and expression of glycogen synthase kinase-3/factor A. EMBO J 1990; 9: 24312438. https://doi.org/10.1002/j.1460-2075.1990.tb07419.x

[5] DOBLE BW, WOODGETT JR. GSK-3: tricks of the trade for a multi-tasking kinase. J Cell Sci 2003; 116: 1175-1186.

[6] JOPE RS, JOHNSON GV. The glamour and gloom of glycogen synthase kinase-3. Trends Biochem Sci 2004; 29: 95-102. https://doi.org/10.1016/j.tibs.2003.12.004

[7] ZENG J, LIU D, QIU Z, HUANG Y, CHEN B et al. GSK3 $\beta$ overexpression indicates poor prognosis and its inhibition reduces cell proliferation and survival of non-small cell lung cancer cells. PLoS One 2014; 9: e91231. https://doi. org/10.1371/journal.pone.0091231

[8] WATCHARASIT P, BIJUR GN, ZMIJEWSKI JW, SONG L, ZMIJEWSKA A et al. Direct, activating interaction between glycogen synthase kinase-3beta and p53 after DNA damage. Proc Natl Acad Sci U S A 2002; 99: 7951-7955. https://doi. org/10.1073/pnas.122062299

[9] LOBERG RD, VESELY E, BROSIUS FC 3RD. Enhanced glycogen synthase kinase-3beta activity mediates hypoxiainduced apoptosis of vascular smooth muscle cells and is prevented by glucose transport and metabolism. J Biol Chem 2002; 277: 41667-41673. https://doi.org/10.1074/jbc. M206405200

[10] SONG L, DE SARNO P, JOPE RS. Central role of glycogen synthase kinase-3beta in endoplasmic reticulum stress-induced caspase-3 activation. J Biol Chem 2002; 277: 4470144708. https://doi.org/10.1074/jbc.M206047200
[11] BIJUR GN, DE SARNO P, JOPE RS. Glycogen synthase kinase-3beta facilitates staurosporine- and heat shock-induced apoptosis. Protection by lithium. J Biol Chem 2000; 275: 7583-7590. https://doi.org/10.1074/jbc.275.11.7583

[12] YAZLOVITSKAYA EM, EDWARDS E, THOTALA D, FU A, OSUSKY KL et al. Lithium treatment prevents neurocognitive deficit resulting from cranial irradiation. Cancer Res 2006; 66: 11179-11186. https://doi.org/10.1158/0008-5472. CAN-06-2740

[13] ELLISON V, STILLMAN B. Biochemical characterization of DNA damage checkpoint complexes: clamp loader and clamp complexes with specificity for 5' recessed DNA. PLoS Biol 2003; 1: E33. https://doi.org/10.1371/journal. pbio. 0000033

[14] KIM HM, KIM CS, LEE JH, JANG SJ, HWANG JJ et al. CG0009, a novel glycogen synthase kinase 3 inhibitor, induces cell death through cyclin D1 depletion in breast cancer cells. PLoS One 2013; 8: e60383. https://doi.org/10.1371/ journal.pone.0060383

[15] YIN JQ, WEN L, WU LC, GAO ZH, HUANG G, et al. The glycogen synthase kinase-3beta/nuclear factor-kappa B pathway is involved in cinobufagin-induced apoptosis in cultured osteosarcoma cells. Toxicol Lett 2013; 218: 129-136. https://doi.org/10.1016/j.toxlet.2012.11.006

[16] XIE N, LI H, WEI D, LESAGE G, CHEN L et al. Glycogen synthase kinase- 3 and p38 MAPK are required for opioidinduced microglia apoptosis. Neuropharmacology 2010; 59: 444-451. https://doi.org/10.1016/j.neuropharm.2010.06.006

[17] JACOBS KM, BHAVE SR, FERRARO DJ, JABOIN JJ, HALLAHAN DE et al. GSK-3beta: A Bifunctional Role in Cell Death Pathways. Int J Cell Biol 2012; 2012: 930710. https:// doi.org/10.1155/2012/930710

[18] MAGA G, HUBSCHER U. Proliferating cell nuclear antigen (PCNA): a dancer with many partners. J Cell Sci 2003; 116: 3051-3060. https://doi.org/10.1242/jcs.00653

[19] WANG S. PCNA: a silent housekeeper or a potential therapeutic target? Trends Pharmacol Sci 2014; 35: 178-186. https://doi.org/10.1016/j.tips.2014.02.004

[20] ROBBINS BA, DE LA VEGA D, OGATA K, TAN EM, NAKAMURA RM. Immunohistochemical detection of proliferating cell nuclear antigen in solid human malignancies. Arch Pathol Lab Med 1987; 111: 841-845.

[21] GUMURDULU D, ERDOGAN S, KAYASELCUK F, SEYDAOGLU G, PARSAK CK et al. Expression of COX-2, PCNA, $\mathrm{Ki}-67$ and p53 in gastrointestinal stromal tumors and its relationship with histopathological parameters. World J Gastroenterol 2007; 13: 426-431. https://doi.org/10.3748/wjg.v13. i3.426

[22] GUZINSKA-USTYMOWICZ K, PRYCZYNICZ A, KEMONA A, CZYZEWSKA J. Correlation between proliferation markers: PCNA, Ki-67, MCM-2 and antiapoptotic protein Bcl-2 in colorectal cancer. Anticancer Res 2009; 29: 30493052.

[23] YU YL, CHOU RH, LIANG JH, CHANG WJ, SU KJ et al. Targeting the EGFR/PCNA signaling suppresses tumor growth of triple-negative breast cancer cells with cell-penetrating PCNA peptides. PLoS One 2013; 8: e61362. https:// doi.org/10.1371/journal.pone.0061362 
[24] VOLM M, KOOMAGI R, MATTERN J. Prognostic-significance of proliferating cell nuclear antigen (pcna) in adenocarcinoma of the lung. Int J Oncol 1995; 6: 359-362. https:// doi.org/10.3892/ijo.6.2.359

[25] GAO X, WANG JY, GAO LM, YIN XF, LIU L. Identification and analysis of glycogen synthase kinase 3 betal interactome. Cell Biol Int 2013; 37: 768-779. https://doi.org/10.1002/ cbin. 10095

[26] FAN X, XIONG H, WEI J, GAO X, FENG Y et al. Cytoplasmic hnRNPK interacts with GSK3 $\beta$ and is essential for the osteoclast differentiation. Sci Rep 2015; 5: 17732. https://doi. org/10.1038/srep17732

[27] GAO X, DAN S, XIE Y, QIN H, TANG D et al. 14-3-3zeta reduces DNA damage by interacting with and stabilizing proliferating cell nuclear antigen. J Cell Biochem 2015; 116: 158-169. https://doi.org/10.1002/jcb.24955

[28] SALUCCI S, BURATTINI S, BATTISTELLI M, BALDASSARRI V, MALTARELLO MC et al. Ultraviolet B (UVB) Irradiation-Induced Apoptosis in Various Cell Lineages in Vitro. Int J Mol Sci 2012; 14: 532-546. https://doi.org/10.3390/ ijms 14010532

[29] CADET J, SAGE E, DOUKI T. Ultraviolet radiation-mediated damage to cellular DNA. Mutat Res 2005; 571: 3-17. https://doi.org/10.1016/j.mrfmmm.2004.09.012

[30] LI L, SAMPAT K, HU N, ZAKARI J, YUSPA SH. Protein kinase $\mathrm{C}$ negatively regulates Akt activity and modifies UVCinduced apoptosis in mouse keratinocytes. J Biol Chem 2006; 281: 3237-3243. https://doi.org/10.1074/jbc.M512167200

[31] YANG J, CRON P, GOOD VM, THOMPSON V, HEMMINGS BA et al. Crystal structure of an activated Akt/ protein kinase B ternary complex with GSK3-peptide and AMP-PNP. Nat Struct Biol 2002; 9: 940-944. https://doi. org/10.1038/nsb870

[32] HUANG L, WU S, XING D. High fluence low-power laser irradiation induces apoptosis via inactivation of Akt/GSK3beta signaling pathway. J Cell Physiol 2011; 226: 588-601. https://doi.org/10.1002/jcp.22367

[33] FONG YC, LI TM, WU CM, HSU SF, KAO ST et al. BMP2 increases migration of human chondrosarcoma cells via PI3K/Akt pathway. J Cell Physiol 2008; 217: 846-855. https:// doi.org/10.1002/jcp. 21568

[34] AVNI D, GLUCKSAM Y, ZOR T. The Phosphatidylinositol 3-kinase (PI3K) inhibitor LY294002 modulates cytokine expression in macrophages via p50 nuclear factor kappa B inhibition, in a PI3K-independent mechanism. Biochem Pharmacol 2012; 83: 106-114. https://doi.org/10.1016/j. bcp.2011.09.025

[35] JOPE RS. Lithium and GSK-3: one inhibitor, two inhibitory actions, multiple outcomes. Trends Pharmacol Sci 2003; 24: 441-443. https://doi.org/10.1016/S0165-6147(03)00206-2

[36] DE BIASIO A, BLANCO FJ. Proliferating cell nuclear antigen structure and interactions: too many partners for one dancer? Adv Protein Chem Struct Biol 2013; 91: 1-36. https://doi.org/10.1016/B978-0-12-411637-5.00001-9

[37] OHAYON D, DE CHIARA A, CHAPUIS N, CANDALH C, MOCEK J et al. Cytoplasmic proliferating cell nuclear antigen connects glycolysis and cell survival in acute myeloid leukemia. Sci Rep 2016; 6: 35561. https://doi.org/10.1038/ srep35561
[38] TSURIMOTO T, STILLMAN B. Replication factors required for SV40 DNA replication in vitro. I. DNA structure-specific recognition of a primer-template junction by eukaryotic DNA polymerases and their accessory proteins. J Biol Chem 1991; 266: 1950-1960.

[39] GILLJAM KM, FEYZI E, AAS PA, SOUSA MM, MULLER $\mathrm{R}$ et al. Identification of a novel, widespread, and functionally important PCNA-binding motif. J Cell Biol 2009; 186: 645-654. https://doi.org/10.1083/jcb.200903138

[40] OSAKI M, KASE S, ADACHI K, TAKEDA A, HASHIMOTO $\mathrm{K}$ et al. Inhibition of the PI3K-Akt signaling pathway enhances the sensitivity of Fas-mediated apoptosis in human gastric carcinoma cell line, MKN-45. J Cancer Res Clin Oncol 2004; 130: 8-14. https://doi.org/10.1007/s00432-0030505-Z

[41] DEVERAUX QL, SCHENDEL SL, REED JC. Antiapoptotic proteins. The bcl-2 and inhibitor of apoptosis protein families. Cardiol Clin 2001; 19: 57-74. https://doi.org/10.1016/ S0733-8651(05)70195-8

[42] KIM R, EMI M, TANABE K, TOGE T. Therapeutic potential of antisense Bcl-2 as a chemosensitizer for cancer therapy. Cancer 2004; 101: 2491-2502. https://doi.org/10.1002/ cncr.20696

[43] BOGDAL MN, HAT B, KOCHANCZYK M, LIPNIACKI T. Levels of pro-apoptotic regulator Bad and anti-apoptotic regulator Bcl-xL determine the type of the apoptotic logic gate. BMC Syst Biol 2013; 7: 67. https://doi.org/10.1186/17520509-7-67

[44] ESSERS J, THEIL AF, BALDEYRON C, VAN CAPPELLEN WA, HOUTSMULLER AB et al. Nuclear dynamics of PCNA in DNA replication and repair. Mol Cell Biol 2005; 25: 9350-9359. https://doi.org/10.1128/MCB.25.21.93509359.2005

[45] LO YH, HO PC, WANG SC. Epidermal growth factor receptor protects proliferating cell nuclear antigen from cullin $4 \mathrm{~A}$ protein-mediated proteolysis. J Biol Chem 2012; 287: 2714827157. https://doi.org/10.1074/jbc.M112.388843

[46] PENSO J, BEITNER R. Lithium detaches hexokinase from mitochondria and inhibits proliferation of B16 melanoma cells. Mol Genet Metab 2003; 78: 74-78. https://doi. org/10.1016/S1096-7192(02)00203-2

[47] SUN A, SHANMUGAM I, SONG J, TERRANOVA PF, THRASHER JB et al. Lithium suppresses cell proliferation by interrupting E2F-DNA interaction and subsequently reducing S-phase gene expression in prostate cancer. Prostate 2007; 67: 976-988. https://doi.org/10.1002/pros.20586

[48] MATSEBATLELA T, GALLICCHIO V, BECKER R. Lithium Modulates Cancer Cell Growth, Apoptosis, Gene Expression and Cytokine Production in HL-60 Promyelocytic Leukaemia Cells and Their Drug-Resistant Sub-clones. Biol Trace Elem Res 2012; 149: 323-330. https://doi.org/10.1007/ s12011-012-9438-1

[49] LAN Y, LIU X, ZHANG R, WANG K, WANG Y et al. Lithium enhances TRAIL-induced apoptosis in human lung carcinoma A549 cells. BioMetals 2013; 26: 241-254. https://doi. org/10.1007/s10534-012-9607-X 